AIR COMMAND AND STAFF COLLEGE

\author{
AIR UNIVERSITY
}

\title{
David Packard's Legacy on American Military Policy
}

\author{
By
}

Benjamin M. Smith, Major, USAF

A Research Report Submitted to the Faculty

In Partial Fulfillment of the Graduation Requirements for the Degree of

\section{MASTER OF OPERATIONAL ARTS AND SCIENCES \\ Advisor: Dr. John G. Terino}

Maxwell Air Force Base, Alabama

25 March 2015 


\section{Report Documentation Page}

Form Approved

OMB No. 0704-0188

Public reporting burden for the collection of information is estimated to average 1 hour per response, including the time for reviewing instructions, searching existing data sources, gathering and maintaining the data needed, and completing and reviewing the collection of information. Send comments regarding this burden estimate or any other aspect of this collection of information,

including suggestions for reducing this burden, to Washington Headquarters Services, Directorate for Information Operations and Reports, 1215 Jefferson Davis Highway, Suite 1204, Arlington

VA 22202-4302. Respondents should be aware that notwithstanding any other provision of law, no person shall be subject to a penalty for failing to comply with a collection of information if it

does not display a currently valid OMB control number.

\begin{tabular}{|c|c|c|}
\hline $\begin{array}{l}\text { 1. REPORT DATE } \\
\mathbf{2 5} \text { MAR } 2015\end{array}$ & 2. REPORT TYPE & $\begin{array}{l}\text { 3. DATES COVERED } \\
\mathbf{0 0 - 0 0 - 2 0 1 5} \text { to 00-00-2015 }\end{array}$ \\
\hline \multirow{3}{*}{\multicolumn{2}{|c|}{ Master Of Operational Arts And Sciences }} & 5a. CONTRACT NUMBER \\
\hline & & 5b. GRANT NUMBER \\
\hline & & 5c. PROGRAM ELEMENT NUMBER \\
\hline \multirow{3}{*}{\multicolumn{2}{|c|}{ 6. AUTHOR(S) }} & 5d. PROJECT NUMBER \\
\hline & & 5e. TASK NUMBER \\
\hline & & 5f. WORK UNIT NUMBER \\
\hline \multicolumn{2}{|c|}{$\begin{array}{l}\text { 7. PERFORMING ORGANIZATION NAME(S) AND ADDRESS(ES) } \\
\text { Air Command And Staff College,Air University,,Maxwell AFB,,AL }\end{array}$} & $\begin{array}{l}\text { 8. PERFORMING ORGANIZATION } \\
\text { REPORT NUMBER }\end{array}$ \\
\hline \multirow{2}{*}{\multicolumn{2}{|c|}{ 9. SPONSORING/MONITORING AGENCY NAME(S) AND ADDRESS(ES) }} & 10. SPONSOR/MONITOR'S ACRONYM(S) \\
\hline & & $\begin{array}{l}\text { 11. SPONSOR/MONITOR'S REPORT } \\
\text { NUMBER(S) }\end{array}$ \\
\hline
\end{tabular}

12. DISTRIBUTION/AVAILABILITY STATEMENT

Approved for public release; distribution unlimited

13. SUPPLEMENTARY NOTES

14. ABSTRACT

15. SUBJECT TERMS

16. SECURITY CLASSIFICATION OF:

\begin{tabular}{c|c|c|c|}
$\begin{array}{c}\text { a. REPORT } \\
\text { unclassified }\end{array}$ & $\begin{array}{c}\text { b. ABSTRACT } \\
\text { unclassified }\end{array}$ & $\begin{array}{c}\text { c. THIS PAGE } \\
\text { unclassified }\end{array}$ & $\begin{array}{c}\text { Same as } \\
\text { Report (SAR) }\end{array}$ \\
\hline
\end{tabular}

\begin{tabular}{c|l}
$\begin{array}{c}\text { 18. NUMBER } \\
\text { OF PAGES } \\
\mathbf{2 9}\end{array}$ & 19a. NAME OF \\
& \\
&
\end{tabular}


AU/ACSC/SMITH, B/AY15

\section{Disclaimer}

The views expressed in this academic research paper are those of the author(s) and do not reflect the official policy or position of the US government or the Department of Defense. In accordance with Air Force Instruction 51-303, it is not copyrighted, but is the property of the United States government. 
David Packard, one half of the computer conglomerate Hewlett-Packard, was a dynamic entrepreneur and servant leader. He built Hewlett-Packard (HP) from a small garage business to one of the greatest electronics companies in the world. As of 2014, HP was the world's second largest computer supplier and ranked 17th on the Fortune 500 list for company size. ${ }^{1}$ Not only did Packard help build a global business colossus, he also served in high-level government positions at the request of two United States Presidents. Despite these enormous responsibilities to his company and his country, it was important for him to found and support several philanthropic endeavors. His leadership standard was to push beyond the ordinary and positively influence the people and endeavors he affected. The overwhelming success of the 1985-1986 Packard Blue Ribbon Commission on Defense Management was the support and credibility it lent to the 1986 Goldwater-Nichols Act (GNA). GNA was not perfect, nor did if fix all the issues faced, then or now, by the Department of Defense (DoD); however the act did make significant positive changes still utilized today. His legacy as a businessman and government icon remains untarnished despite the continuing issues regarding DoD and acquisition reform. Although many commissions, reports, and studies which were led by titans of industry and the military have been implemented over the years, issues of defense management still abound. As he prophetically pointed out in his acceptance speech for the Francis Boyer Award in 1986, "It is clear that defense acquisition typically differs from this commercial model in almost every respect."2 Although criticized for failing to provide enough tangible changes to the military acquisition process, his recommendations are enduring principles of successful organizational execution. In this paper, I will examine the impact David Packard had on the military and whether those impacts were positive or negative. I will start by reviewing his upbringing and background, answering the question: "Who was David Packard?” It is important to note his values and beliefs 
based on his experience and how they influenced his actions serving in his government capacities. Then I will focus on the history surrounding his government roles and key contributions while he served in them. This will frame the environment in which he led policy discussions and decisions from 1969 to 1986. Finally, with that as the context, I can analyze his impact and ultimately his legacy on the Pentagon and the U.S. military. Not only whether it was positive or negative, but more importantly to what extent he accomplished his goals and what factors may have enabled or constrained his efforts.

\section{American Entrepreneur}

David Packard was an innovative entrepreneur who understood the importance of sacrifice and service to others; these traits instilled during his upbringing in Pueblo, Colorado during the Great Depression would propel him to enormous success as the co-founder of the electronics company Hewlett-Packard. Not only did he demonstrate selflessness but also a strong technical interest and aptitude across a range of technologies and processes from radio to explosives. ${ }^{3}$ A multibillionaire at the time of his death, he used his company's reputation, his wealth, and his leadership to advance the field of electronics, supported the government with military capability, and personally served in high-level positions. In many of these roles he was determined to help reform not only acquisition, but also the structure of the United States military as a whole. The opening remarks of his biography certainly paint an accurate portrait, “Dave Packard's influence on the electronics industry, management and philanthropy was nothing short of extraordinary. Friends and employees described him as warm, generous, humorous and no-nonsense." ${ }^{4}$

Born in 1912, David Packard grew up in an upper middle-class family. His mother was a school teacher and his father was a lawyer. ${ }^{5}$ His parents raised him in Pueblo, Colorado where he 
demonstrated a self-reliant, curious, and self-starter attitude from an early age. He gravitated toward science and technology. He spent hours reading the science section of the World Book Encyclopedia, specifically the pages dealing with about technology like trains and generators. ${ }^{6}$ In fact, he built his own radio from spare parts for his family’s enjoyment at twelve years old. Packard wanted to be an engineer from a young age even though his father wanted him become a lawyer like him.

Dave's interests went beyond technology. He enjoyed the outdoors and started exploring his hometown of Pueblo and playing sports. Packard writes in The HP Way that, "I enjoyed athletics and learned some lessons that were helpful in managing Hewlett-Packard.” One of those important lessons was, "Given equally good teamwork, the team with the strongest will to win will prevail., ${ }^{7}$ He was on the football, basketball, and track teams in high school and would also play these sports in college. Teamwork and relationships influenced his perspective early in his life and became central not only to his education, but also played a critical role throughout his business and government endeavors. Again, a point he advanced in his book where he stated, "Get the best people, stress the importance of teamwork, and get them fired up to win the game.” ${ }^{8}$ He graduated from Centennial High School in 1930 just as the Great Depression was starting. ${ }^{9}$ His time in Pueblo was influential enough to ensure his charity foundation’s headquarters operate there to this day. ${ }^{10}$

No doubt as he experienced the hardships of the Great Depression, a firm foundation of tenacity and self-reliance developed that influenced his work ethic in college and for years to come. David Packard attended college during the Great Depression, a time when university attendance rates dropped. Even though it was very difficult financially he matriculated at a respected university far from home and paid for his tuition with money from manual labor jobs 
he worked during the summer. He attended Stanford University and received a Bachelor of Arts degree in 1934. During his time at Stanford he met a professor and mentor named Fred Terman who helped further cultivate his interest in technology. Terman would play a significant role in spurring Packard's journey toward a master's degree, cultivating relationships with other students at Stanford, and ultimately starting his company with Bill Hewlett.

After graduation, Packard was hired by General Electric and worked there from 19361938. Again, he was in a very good position; securing a job, but not just any job. General Electric (GE) would have been the goal of most accomplished engineers. GE had only been established for 44 years at this time. It was a prominent electric manufacturing company that played a vital role in the construction of the Empire State Building in 1930, could boast that they employed the first US industrial scientist to win the Nobel Prize, and in 1938, invented the fluorescent lamp; it was a draw to many bright engineers like David Packard. ${ }^{11}$ An Electrical Engineer working for GE in 1936 would have been like a computer programmer whose first job was working for Microsoft in the early 1990s. While he was still an employee for General Electric, Packard requested a sabbatical to pursue his master's degree in electrical engineering and graduated from Stanford in $1939 .{ }^{12}$

After working for GE and finishing his graduate degree, he began to receive encouragement from his mentor, Fred Terman, to develop cutting-edge technical solutions. With this help he started Hewlett-Packard with a friend he met at Stanford, Bill Hewlett, in 1939 in a garage with startup capital of around $\$ 538$ dollars. ${ }^{13}$ That capital equates to approximately $\$ 9,000$ dollars in today’s money. Their first product was a resistance-capacitance audio oscillator ${ }^{14}$ used to test sound equipment. ${ }^{15}$ Although Bill Hewett came up with the design, David Packard was quick to demonstrate his business savvy by convincing his partner to dub the 
invention the HP model 200A to help give it a more reputable appearance. ${ }^{16}$ Their oscillator was a leap in technology and secured Walt Disney as a customer in 1940. Disney would buy eight HP model 200B oscillators to test sound equipment in their on-site movie theaters. ${ }^{17} \mathrm{HP}$ was where Packard proved to be an expert administrator and Hewlett provided technical innovations and grew into the world's largest producer of electronic testing and measurement devices. It also became a major producer of calculators, computers, and laser and ink jet printers. ${ }^{18}$ Packard's gift for leadership and administration was demonstrated in several of his initiatives at HewlettPackard. For example, during a meeting in 1958 he discussed his " 11 simple rules.” His 11 rules focused mainly on mutual respect, healthy workplace relationships, and taking care of people. They were not only simple rules, but also uncommon ideas for industrial growth during that time.

He was also very instrumental in other unique operating approaches like HP-issued bonuses and stock, employee profit sharing, health insurance, decentralized decision making, developed flextime, and made famous the concept of management by walking around before they were popular programs and catch phrases. It is no surprise that Bill is described as the pioneer and Dave as a father and guiding spirit. ${ }^{19}$ Dave also ran the business while Bill served with the U.S. Army during WWII. ${ }^{20}$ Packard served as Hewlett-Packard's president from 1947 to 1964, Chief Executive Officer from 1964 to 1968, and Chairman of the Board from 1964 to 1968 and from 1972 to $1993 .^{21}$

David Packard certainly demonstrated an above average care and sensitivity for his employees but it didn't stop at HP. He was a world-class philanthropist who used his fortune to better the environment and people around him. From the early 1980s until his death, Packard dedicated much of his time and money to philanthropic projects. The two most well-known are 
the Monterey Bay Aquarium and the Lucile Salter Packard Children's Hospital at Stanford University. His will gave most of his estate to the David and Lucile Packard Foundation which donates over \$250 million dollars each year for conservation, science, population and reproductive health, communities, and local grant-making. ${ }^{22}$ All three Packard daughters sit on the Foundation's board of trustees. ${ }^{23}$

So what was it about his background that made him willing to sacrifice so much personally to serve in his government roles? His immense successes running his international company could have been enough of a reason to turn down a government leadership role, but he did not. Looking at his personality in context of his life experience to this point it is apparent he valued personal sacrifice and responsibility for others. He valued relationships, personal leadership, and the "American dream”; not only for himself but for those around him, too. He wasn't a pushover or soft, but valued hard work and success through teamwork and innovation. That innovation was as much for technology as it was for pioneering new ways to care for employees. If he thought he could impart these principles to the military, improve lives, and contribute to increased output it is apparent that he would want to be a part of it.

His background including his upbringing and values, his education, work experience at GE, and innovative approach learned by starting his own company shaped how he would face the challenges of government service.

\section{From Business Leader to Government Leader}

If co-founding one the largest and most innovative companies to grow out of the Silicon Valley was not enough, David Packard also served as the Deputy Secretary of Defense (Deputy SecDef) from 1969 to 1971, he was the Chairman of the Business Council from 1973-1974, and led President Reagan’s Blue Ribbon Commission on Defense Management from 1985-1986; all 
at great personal sacrifice. In the three years he served as the Deputy SecDef alone, he gave up an estimated \$25 million dollars in salary and stock options to avoid any conflict of interest with his company's government accounts. David Packard was bright, energetic, and understood the meaning of service to his country. It is no surprise he was asked to serve in elevated roles in the government at the request of the President. He served in the government during a time of turbulence; a culmination of military disappointments causing widespread debate over the adequacy of defense management. With David Packard's help in key roles over the next 17 years there were some of the most wide-spread Department of Defense reforms in almost forty years.

The turbulence in the DoD wasn't new but was rapidly becoming of greater concern after repeated military shortcomings that highlighted organizational, leadership, and equipment inadequacies. One of the most damaging aspects was a competitive service culture that placed each service at odds with the others for resources based on perceived mission importance and lacked a single decision maker on the Joint Chiefs of Staff who could arbitrate and finalize disputes in the interest of national defense. Any type of reorganization or realignment of procurement authority would be met with dissent as each service wanted to protect its power and money. ${ }^{24}$ There were a myriad of military failures that led up to Packard's role as the Deputy SecDef and then the Packard Commission working to change the fundamental organization, procurement process, and leadership responsibilities. Starting in 1954, the United States was involved in several conflicts, interventions, and terrorist attacks that would demonstrate a woefully inadequate joint operations mindset, organizational leadership, and equipment shortcomings causing frustration at every level of military and government leadership. Beginning with Vietnam 1954-1975, then the Iran Hostage Crisis (Operation Eagle Claw) in April 1980, and ending with both the Beirut Barracks Bombing and the issues with the Invasion of Grenada 
in October 1983 (Operation Urgent Fury). Most of the issues were systemic ranging from a lack of unification in the field, joint operations issues, and cumbersome and confused chains of command that resulted in disasters in communication and coordination. ${ }^{25}$ It is during this period that David Packard would serve the leadership of the US in several important roles. First, he was the Deputy Secretary of Defense for President Nixon and Secretary of Defense Melvin Laird. Second, from 1973 to 1974 he served as the Chairman for The Business Council. A council organized by the Secretary of Commerce in 1933 to serve as a key bipartisan advisory board providing business expertise to the US government. Third, he served as chairman of the President’s Blue Ribbon Commission of Defense Management in 1985 and 1986. I will discuss each position and the contributions in turn.

David Packard's impact is even more impressive when viewed in light of the turbulence and modernization that was occurring in the Department of Defense at this time. He was a dynamic businessman who brought an entrepreneurial spirit and teambuilding experience to the government. Unfortunately, his contributions and support of Secretary of Defense Laird as the Deputy Secretary of Defense are often overlooked completely. Upon entering office in 1969, President Richard M. Nixon appointed Packard US Deputy Secretary of Defense. Packard served until 1971, when he resigned and returned to Hewlett-Packard the next year as Chairman of the Board. As Deputy Secretary of Defense his leadership style influenced the Secretary of Defense Melvin Laird, welcomed military policies, increased positive relationships with senior military officers, and shaped defense procurement.

There were several policies and practices instituted during Laird's tenure as Secretary of Defense that aligned with beliefs and practices held by Packard himself. Whether Laird borrowed from Packard's ideas or Laird hired Packard for their shared thinking is unclear. 
Reality most likely lies somewhere in between and both men supported the other to institute policies that might repair the relationships and improve the functions of the US military and the office of Secretary of Defense. One good example is an effort to rebuild relationships with the top military leaders and decentralize decision-making, much like what he accomplished at HP. Relationships between the office of the Secretary of Defense and the Service Chiefs were strained after Robert McNamara and Clark Clifford left office in the late 60s. They had cut the service chiefs out of the information and decision making process especially during Vietnam. As in his business dealings, Packard's emphasis on relationships served him well during his tenure in the government. This personal leadership style matched well with Laird's and he would later comment that "Mel wanted to implement a plan he called participatory management, and this fit well with the HP policies I wanted to put into effect there.”26 Packard came in and extended his charismatic and kind personality. He invited them to an annual deer hunt to establish a relationship based on trust. He and Hewlett even brought and cooked the food. He wanted to build “friendship and collaboration.”27

As the relationships improved so did the decision making process. Now that the service chiefs were welcomed into the process and asked to provide guidance, more efficient work could be accomplished on procurement. For example, the service budgets would be developed by the officers and sent for scrutiny and approval instead of the centralized approach under McNamara. This continued a cycle of trust building and more participation and collaboration between Laird and Packard and the military components. This paved the way for Packard to apply his business know-how to military procurement and begin to improve the acquisition process starting with the workforce. 
While addressing an industry group in 1970, Packard gave his blunt assessment on the state of defense procurement and acquisition reform when he said, "Frankly, gentlemen, in defense procurement, we have a real mess on our hands, and the question you and I have to face up to is what we are going to do to clean it up. ${ }^{28}$ He believed one of the major deficiencies of military acquisition was the lack of training and education for military and civilian personnel. Although Secretary of Defense Robert McNamara had established the Defense Weapon Systems Management School (DWSMS) in 1964, Packard disagreed with its mission statement. DWSMS focused on familiarizing individuals with standardized terms and policies but lacked the desire to treat them as a professional workforce. ${ }^{29}$ In response to this issue with acquisition workforce training and knowledge Laird and Packard established the Defense Systems Management School (DSMS), later renamed to Defense Systems Management College, the forerunner to the modern Defense Acquisition University. "DSMS reflected Packard’s belief that program managers required an in-depth knowledge of acquisition processes and required training to support this.”30 This intent persists in the robust training and certification process that currently exists in the acquisition career field. Although some of the online courses are criticized for their lack of effectiveness, that is a reflection of poor implementation and accountability, it does not reflect Packard's philosophy for well-trained and highly motivated professionals.

Another major military workforce reform that Packard supported and helped initiate was the all-volunteer military force. ${ }^{31}$ Laird had established a large fund of $\$ 1.3$ billion dollars to transition the military to a small but higher paid all-volunteer force and he relied on Packard to advocate for the program and analyze options for how to allocate the funds starting in fiscal year 1972. Packard believed in the program and it was in line with what they were doing for the procurement personnel, ensuring a highly motivated, trained, and knowledgeable labor force. He 
did prefer to move cautiously but that should not be interpreted as a lack of faith in the program. His caution translated into a recommendation for a "large contingency fund to deal with unforeseen problems.”32

David Packard resigned as the Deputy Secretary of Defense in 1971. As Vietnam was being handed over to the South Vietnamese during Laird's Vietnamization process and many of their major initiatives had taken shape, Packard may have felt the need to return to the helm of his global firm. His letter to President Nixon only cites personal reasons for his resignation. It is entirely possible that the challenges associated with significant changes in core elements of the company's product lines stimulated Packard's belief he needed to devote more time to HP business than defense business. Technical change spurred growth in business computing, in general, and for his company, in particular, in the early 1970s with the use of laser interferometers to produce microchips and the introduction of handheld scientific calculators, both HP innovations. ${ }^{33}$

After leaving the Defense Department, Packard was a prominent advisor to the White House on defense procurement and management. ${ }^{34}$ As evident in his capabilities, non-partisan support of the government, and the faith both Democrats and Republicans had in him, Packard would serve in two other roles in the government that required less of his time. First, from 1973 to 1974, David Packard served as the Chairman for the President's Business Council. The Business Council is a non-partisan group that was formed by the Secretary of Commerce in 1933 to help the nation get out of the Great Depression. They are still a consulted group and outline their mission on their website: "The Business Council limits itself to 150 Active members, each of whom is selected on the basis of personal qualities and position as the chief executive officer of a leading private sector business from commerce and industry. The Council seeks a wide 
representation of business leaders, both from a broad range of industrial and service sectors as well as from a geographical basis. There are no political qualifications for membership.” ${ }^{35}$

Second, he was a member of the Trilateral Commission from its inception in 1973 to 1981. This commission was created to strengthen communication and cooperation between Europe, North America, and Asia. Founded by prominent businessman David Rockefeller in 1973, it relied on prominent private sector business leaders as the cornerstone of its leadership cadre, and leveraged their influence and experience to help solve global issues. ${ }^{36}$

After serving in these "quieter" advisory roles, David Packard was called on to play a major role in not only acquisition change but the most significant military reform since the National Security Act of 1947. Appointed in 1985 by President Reagan to chair the Blue Ribbon Commission on Defense Management, Packard provided the political leverage to reinforce not only those initiatives he started or wanted to start as Deputy Secretary of Defense, but also aided the hard-fought military reforms known as the Goldwater-Nichols Act (GNA). Before Packard was appointed the Commission's Chair, the battle for military reform began three years earlier in 1982 and lasted until 1986. The reforms were hotly debated amongst civilian and military leadership. In fact, General Jones, Chairman of the Joints Chiefs of Staff, took a controversial stand in support of military reforms that made waves with the Secretary of Defense and the Joint Chiefs of Staff and was the first major salvo in the fight for change. "In late 1982, the Joint Chiefs of Staff, responding to a study by Secretary of Defense Caspar Weinberger, recommended against major JCS reorganization. Secretary Weinberger and President Ronald Reagan supported this recommendation, and the administration took for the first time an official position in opposition to JCS reform. ${ }^{\text {37 }}$ In light of this stance by both the Secretary of Defense and the President, the Packard Commission would become a significant ally to Senator 
Goldwater, who by 1985 had been driving the GNA for over three years. The Packard Commission carried the confidence of the administration and could help smooth the path for military reform by influencing the President. Unfortunately, he is often overlooked or criticized unfairly using past and present program cost overruns and schedule delays as evidence against his contributions. Much of this erroneous and vague evidence was and is based on incorrect assumptions and a limited understanding of the priorities, goals, and identified limitations by David Packard and his commission team.

By 1985, acquisition schedule delays and major cost overruns came under increased scrutiny from both US citizens and political leaders. To analyze and change this trend, President Reagan turned to Packard and his business prowess to give an unvarnished and experienced opinion on the problems and potential solutions. Although the instigating problem was procurement issues, President Reagan did not put strict boundaries on the Packard Commission and they were free to look at the military in totality. Wanting to protect his power and ensure larger reforms were kept in check, Weinberger discussed his concerns with Packard to ensure he only looked at procurement. Packard understood people and the sensitivity of potential changes and continued to assure Weinberger the thrust was acquisition. While the main analysis focused on acquisition, Packard kept the fact the commission would also look at other military organization issues closely guarded. To this end, the Packard Commission team met with the GNA team to discuss the merits of their efforts and decided there was common ground and interest for the Packard Commission to support them.

Although he pushed the boundaries of change Packard wanted to go much further with the reform recommendations including going to a single service like in Canada. ${ }^{38}$ This wasn’t a new idea. The Army attempted, and failed, to create a single military department in 1943. The 
idea was for a single department with one Chief of Staff and assistant secretaries for air, land, and sea components. ${ }^{39}$ Although this was one of the more extreme examples, both the Packard Commission and GNA were watered down by political pressure. The reforms were not well received and pushing the envelope may have caused them to fail. The idea was to get something rather than nothing at all. So while they are criticized for not doing enough they accomplished more sweeping reforms before or since.

David Packard and the Packard Commission produced four progress reports and a final report providing recommendations for reform of not only the $\mathrm{DoD}$ acquisition process and structure, but also other far reaching military reforms. The First Interim Report covered four major areas including national security planning and budgeting, military organization and command, acquisition organization and procedures, and government-industry accountability. Packard believed the root cause of military problems rested with the planning and budgeting process. ${ }^{40}$ Planning and budgeting changes recommended included submission of a two-year Presidential budget to Congress and then Congress production and implementation of a five-year budget based on the original submittal. These budgets would help promote stability by providing time to analyze military planning options. ${ }^{41}$ Another recommendation was for better milestone authorization and baselining. It would ensure two milestone reviews for programs and, if a program was performing well against their schedule and cost baseline, the milestone scrutiny could be reduced.

The Second Report was concerned primarily with the acquisition process. This report outlined six features of successful procurement programs: clear command channels, stability, limited reporting requirements, small, high-quality staffs, communications with users, and prototyping and testing. Based on these identified features three recommendations were made to 
move in that direction: establish the new position of the Under Secretary of Defense and authorization of an additional Level II appointment in the Office of the Secretary of Defense (OSD). Second, place a "high priority on building and testing prototype systems to demonstrate that new technology can substantially improve military capability.” Third, restructure the Joint Requirements and Management Board (JRMB) co-chaired by the new Under Secretary of Defense Acquisitions and the vice chairman of the Joint Chiefs of Staff. This would allow for greater involvement, insight, and influence of weapon system requirements early enough in the process to affect cost and performance.

The Third Report was entitled, “National Security Planning and Budgeting”, focused on future planning that involved a five year budget from the president and the JCS developing their overarching military strategy including the force structure to support the strategy. The intent was to ensure military operational requirements were being inserted and updated in a timely and effective manner to support strategy changes in the field. The Fourth Report was titled, "Conduct and Accountability” and dealt with the government-contractor relationship that appeared to be a source of mistrust and waste.

Secretary Weinberger was adamant that Packard should only focus on acquisition reforms. He opposed reforms because he did not want to erode his power, lose budget momentum, could not take criticism for his management, and wanted to avoid Congressional meddling. ${ }^{42}$ The Packard Commission deviated from making recommendations only regarding Acquisition Reform. The final report would encapsulate the recommendations from the first four reports and expound on them by stating in chapter two that to accomplish the defense planning and budgeting changes required changes in the defense establishment. He specifically supported GNA by recommending increased roles and responsibilities for Unified and Specified 
Commands (CINCs), the Chairman of the Joint Chiefs of Staff, and established a joint transportation command.

These recommendations stemmed from a year's worth of research and analysis by top government and civilian leaders; however several were influenced by discussions held between the Packard team and GNA staff. It should also be noted that the GNA was also influenced in regards to procurement reform recommendations it provided. The GNA recommendations covered nine key objectives: strengthen civilian authority, improve military advice to the president, place clear responsibilities on the unified commanders in chief for mission accomplishment, ensure that a unified commander's authority is commensurate with his responsibilities, increase attention to strategy formulation and contingency planning, provide the more effective use of resources, improve joint officer management, enhance effectiveness of military operations, and improve Defense Department management and administration. ${ }^{43}$ Almost all of them were reflected in the Packard Commission's recommendations that were submitted just months before the GNA was signed in 1986.

It is not surprising Packard's team submitted their final report shortly before the GNA was voted on and ultimately signed by the President. The Packard Commission was initiated by the President and since it was his commission he would undoubtedly be a proponent of reasonable findings. President Reagan was originally opposed to military reform; however, the Packard Commission helped influence his change of opinion and he signed the GNA in late 1986.

\section{David Packard's Legacy}

David Packard developed and drove military and acquisition reforms that persist to this day and although not perfect, he was the right type of visionary leader injected into the system at 
a very turbulent and malleable time in military history. Although the inherent issues in the system would have hampered a less dynamic leader even more. Although he made positive inroads, his contributions were somewhat limited by the government system and poor implementation. Packard's post Deputy Secretary of Defense tenure statement is also applicable to the Blue Ribbon Commission recommendations, “Looking back today, I feel that Mel Laird’s team contributed to a positive change in U.S. military capability. But there is a definite limit to the extent that civilian criteria can be applied to the military."44 The understanding is that the government system and processes are different from those in the civilian industry. Even a man of his talent and accomplishments in business will find it difficult to meet the bureaucratic resistance found in the government. Not all successful business traits have seamless application in the government system. However, two characteristics that do have direct application in business and government are relationship building and servant leadership. David Packard possessed both and made a lasting positive impact on the American military. As Deputy Sec Def. he started the Professional Acquisition Workforce through initiatives like the Defense University and helped lay the groundwork for an all-volunteer military. Later, as the chairman for the Blue Ribbon Commission on Defense Management he helped establish clear roles and responsibilities for decision makers in DoD. He also reinforced the GNA to increase the power of the CJCS, mandate joint procurement and career management, strengthen combatant command authority, improve national planning and strategy making, implement a more robust budgeting process, and continued to stress the value of a highly trained and professional acquisition workforce. Implementation issues boiled down to the workforce and almost every reform has addressed workforce quality, authority, and incentives. A Congressional Research Service report got it right when it stated, "Despite the hundreds of disparate recommendations to improve defense 
acquisitions, most reports seeking to address the fundamental weakness of the system arrive at the same conclusion: the key to good acquisition is having a good workforce and giving them the resources incentives and authority to do their job." ${ }^{45}$ This was ultimately what David Packard tried to bring to the military as he had so successfully accomplished at HP. He took care of his people in unique and innovative ways while he trained and rewarded them. If acquisition reform is to truly change, it has to focus on the workforce as the most important component of change. One the workforce is strengthened, then, and only then, can you implement more complex policy reform. When the workforce doesn't understand, can't understand, or is unwilling to understand, policy changes cannot take root or be implemented properly to have an effect on the system.

The current Under Secretary of Defense for Acquisition, Technology, and Logistics, Frank Kendall, developed a concept named Better Buying Power aimed at reforming the acquisition process. These current reform efforts are largely based on Packard's timeless advice from 1971 and 1986. Mr. Kendall has not only based his current reforms on Packard's thoughts; he has gone as far as to post them in the Pentagon as a testament to their timeless nature. ${ }^{46}$ Packard’s legacy and influence clearly carries forward to today, in ideas including helping the services do a better job by providing appropriate oversight, good program managers with authority and responsibility, and controlling cost through trade-offs. These sentiments are echoed in a 2014 Congressional Research Service report that stated: “Many of the DoD’s current initiatives to improve acquisitions can be traced back to the ideas and recommendations in the Packard Report."47 The reason Packard's legacy is sullied is because he developed sound practices however, the implementation of his ideas has repeatedly been flawed, fallen short, or needed additional guidance that has never been developed or approved. For example, Packard envisioned program managers reporting directly to the Program Executive Officer (PEO). While 
the PEO position was established, most program mangers do not report directly to them for a variety of reasons. Regardless of why the services don't have program manager's report to the PEO, it certainly dilutes the accountability of the program manager and the oversight of the PEO.

Another good example is the Defense Acquisition University and how the training doesn't fulfill Packard's vision of a professional Acquisition cadre. Too many of the classes are online with little to no accountability mechanisms to ensure personnel are actually learning the material. Not only is the formal education process lacking accountability but also, the on-the-jobtraining (OJT) that should provide the remaining knowledge is not enforced consistently for all personnel. For example, the Career Field and Experience Training Plan is a checklist of OJT that should occur for program managers in their first six years of service. It covers many of the important tasks and processes that should be learned and each knowledge item is signed off by the supervisor when they feel the employee has mastered that item. Yet, too often it isn't used or even required. Furthermore, engineers in acquisition programs do not have a CFETP. So, too often, I personally used the program manger one since many of the tasks and knowledge items are similar. Although these tools like DAU online courses and the CFETP exist, their implementation and use certainly would not meet the high standards of building acquisition professionals that David Packard intended.

David Packard was a remarkable person, who used his passion for technology and people to start a company in a garage and grow it into a global powerhouse. Because of his dynamic, people-oriented personality he was asked to sacrifice personal gain and help lead the U.S. DoD during an extremely turbulent and divisive time. He succeeded in many ways, ushering lasting changes that have positively impacted the people and the missions of the U.S. military. Although his improvements were not as many or as far-reaching as he had hoped, they are still very 
AU/ACSC/SMITH, B/AY15

impressive for the amount of resistance he encountered. Many of these improvements and reforms are timeless and would have more prevalence if they had more robust implementation, in line with Packard's deep commitment to technology innovation and focus on people. The DoD still struggles with the enormity of his recommendations and how best to implement them yet, there are many that use his example to spur change and innovation, all while lifting up the people that make it all happen. 


\section{Endnotes}

${ }^{1}$ Hoovers website. 2014. http://www.hoovers.com/company-information/cs/companyprofile.HEWLETT-PACKARD_COMPANY.ce061ed249e20ed3.html (accessed February 21, 2015)

${ }^{2}$ David Packard, Management of America's National Defense (Washington D.C.: American Enterprise Institute Press, 1987), 7

${ }^{3}$ David Packard, The HP Way: How Bill Hewlett and I Built Our Company (New York: HarperCollins Publishers, Inc., 2006), 6

${ }^{4}$ Hewlett-Packard corporate website, "Dave Packard Biography" (January 2001) http://hp.com/retiree/history/founders/packard/dave.pdf (accessed November 18, 2014)

${ }^{5}$ Astro Databank. August 31, 2012. http://www.astro.com/astro-databank/Packard\%2C_David (accessed February 18, 2015)

${ }^{6}$ David Packard, The HP Way: How Bill Hewlett and I Built Our Company (New York: HarperCollins Publishers, Inc., 2006), 6

${ }^{7}$ David Packard, The HP Way: How Bill Hewlett and I Built Our Company (New York: HarperCollins Publishers, Inc., 2006),11

${ }^{8}$ David Packard, The HP Way: How Bill Hewlett and I Built Our Company (New York: HarperCollins Publishers, Inc., 2006),12

${ }^{9}$ The Pueblo Chieftain, October 16, 2014. http://www.chieftain.com/opinion/2980311119/packard-pueblo-david-hewlett (accessed February 18, 2015).

${ }^{10}$ The David and Lucile Packard Foundation, http://www.packard.org/ (accessed February 18, 2015)

${ }^{11}$ General Electric website, http://www.ge.com/about-us/history (accessed February 16, 2015)

${ }^{12}$ Hewlett-Packard corporate website, "Dave Packard Biography" (January 2001) http://hp.com/retiree/history/founders/packard/dave.pdf (accessed November 18, 2014)

${ }^{13}$ Hewlett-Packard corporate website, "Dave Packard Biography" (January 2001) http://hp.com/retiree/history/founders/packard/dave.pdf (accessed November 18, 2014)

${ }^{14}$ Hewlett-Packard corporate website, "Dave Packard Biography" (January 2001) http://hp.com/retiree/history/founders/packard/dave.pdf (accessed November 18, 2014)

${ }^{15}$ Mary Bellis, About Money, n.d.

http://inventors.about.com/od/hstartinventors/a/William_Hewlett.htm (accessed February 16, 2015)

${ }^{16}$ Mary Bellis, About Money, n.d.

http://inventors.about.com/od/hstartinventors/a/William_Hewlett.htm (accessed February 16, 2015)

${ }^{17}$ Mary Bellis, About Money, http://inventors.about.com/od/hstartinventors/a/William_Hewlett.htm (accessed February 16, 2015)

${ }^{18} \mathrm{http}: / /$ www.edisontechcenter.org/DavidPackard.html (accessed February 16, 2015)

${ }^{19}$ Hewlett Packard corporate website, http://www8.hp.com/us/en/hp-information/abouthp/history/hp-timeline/timeline.html (accessed February 18, 2015)

${ }^{20}$ Hewlett Packard corporate website, http://www8.hp.com/us/en/hp-information/abouthp/history/hp-timeline/timeline.html (accessed February 18, 2015)

${ }^{21}$ http://www.edisontechcenter.org/DavidPackard.html (accessed February 16, 2015) 
22 The David and Lucile Packard Foundation, http://www.packard.org/ (accessed February 18, 2015)

${ }^{23}$ http://www.edisontechcenter.org/DavidPackard.html (accessed February 16, 2015)

24 James Kitfield, Prodigal Soldiers, (Washington D.C.: Potomac Books, Inc., 1997)

${ }^{25}$ James R. Locher III, Victory on the Potomac: The Goldwater-Nichols Act Unifies the Pentagon (Need City: Texas A\&M University Press, 2004), 33-55

${ }^{26}$ David Packard, The HP Way: How Bill Hewlett and I Built Our Company (New York: HarperCollins Publishers, Inc., 2006), 176

${ }^{27}$ David Packard, The HP Way: How Bill Hewlett and I Built Our Company (New York: HarperCollins Publishers, Inc., 2006),176-177

${ }^{28}$ Evelyn Layton, The Defense Acquisition University: Training Professionals for the Acquisition Workforce 1992-2003 (Fort Belvoir, Virginia: Defense Acquisition University Press, 2007), 5

${ }^{29}$ Evelyn Layton, The Defense Acquisition University: Training Professionals for the Acquisition Workforce 1992-2003 (Fort Belvoir, Virginia: Defense Acquisition University Press, 2007), 6

${ }^{30}$ Evelyn Layton, The Defense Acquisition University: Training Professionals for the Acquisition Workforce 1992-2003 (Fort Belvoir, Virginia: Defense Acquisition University Press, 2007), 7

${ }^{31}$ Robert K. Griffith, U.S. Army's Transition to the All-Volunteer Force, 1868-1974 (Washington D.C.: Diane Publishing Co., 1997), 58

${ }^{32}$ Robert K. Griffith, U.S. Army's Transition to the All-Volunteer Force, 1868-1974 (Washington D.C.: Diane Publishing Co., 1997), 59

${ }^{33}$ Hewlett Packard corporate website, http://www8.hp.com/us/en/hp-information/abouthp/history/hp-timeline/timeline.html (accessed February 18, 2015)

${ }^{34}$ http://www.edisontechcenter.org/DavidPackard.html (accessed February 16, 2015)

35 http://www.thebusinesscouncil.org/about (accessed January 10, 2015)

${ }^{36}$ http://www.Trilateral.org (accessed November 16, 2014)

37 James R. Locher III, Victory on the Potomac: The Goldwater-Nichols Act Unifies the Pentagon (Need City: Texas A\&M University Press, 2004), 392

38 James R. Locher III, Victory on the Potomac: The Goldwater-Nichols Act Unifies the Pentagon (Need City: Texas A\&M University Press, 2004), 391-398

39 James R. Locher III, "Has It Worked? The Goldwater-Nichols Reorganization Act" (Naval War College Review, 95-115, 2001) 97

${ }^{40}$ David Packard, Management of America's National Defense (Washington D.C.: American Enterprise Institute Press, 1987), 2

${ }^{41}$ David Packard, "A Quest for Excellence: Final Report to the President" (Presidential Commission, Washington D.C., 1986), 25

42 James R. Locher III, Victory on the Potomac: The Goldwater-Nichols Act Unifies the Pentagon (Need City: Texas A\&M University Press, 2004),

43 James R. Locher III, "Has It Worked? The Goldwater-Nichols Reorganization Act" (Naval War College Review, 2001), 95-115.

${ }^{44}$ David Packard, The HP Way: How Bill Hewlett and I Built Our Company (New York: HarperCollins Publishers, Inc., 2006), 185

${ }^{45}$ Moshe, Schwartz, Reform of the Defense Acquisition System. Congressional testimony, (Washington D.C.: Congressional Research Service, 2014)

${ }^{46}$ Frank Kendall, "The Original Better Buying Power: David Packard Acquisition Rules 1971" (Defense AT\&L: May-June, 2013: 2-5) 
AU/ACSC/SMITH, B/AY15

${ }^{47}$ Frank Kendall, "The Original Better Buying Power: David Packard Acquisition Rules 1971" (Defense AT\&L: May-June, 2013: 2-5) 


\section{Bibliography}

Alic, John A. "Managing U.S. Defense Acquisiton." Enterprise and Society, 2013: 1-36.

Bellis, Mary. About Money. n.d.

http://inventors.about.com/od/hstartinventors/a/William_Hewlett.htm (accessed February 16, 2015).

Birkeler, John, and et al. From Marginal Adjustments to Meaningful Change. Santa Monica: RAND Corporation, 2010.

Christensen, Dr. David S., Capt David A. Searle, and Dr. Caisse Uickery. "The Impact of the Packard Commision's Recomendations on Reducing Cost Overruns." Acquisition Review Quarterly, 1999: 251-262.

Griffith, Robert K. U.S. Army's Transition to the All-Volunteer Force, 1868-1974. Washington D.C.: Diane Publishing Co., 1997.

J. Ronald Fox, et al. Defense Acquisition Reform 1960-2009: An Elusive Goal. Washington D.C.: Army Center of Military History, 2011.

Kendall, Frank. "The Original Better Buying Power: David Packard Acquisition Rules 1971." Defense AT\&L: May-June, 2013: 2-5.

Kitfield, James. Prodigal Soldiers. Washington D.C.: Potomac Books, Inc., 1997.

Layton, Evelyn. The Defense Acquisition University: Training Proffessionals for the Acquisition Workforce 1992-2003. Fort Belvoir, Virginia: Defense Acquisition University Press, 2007.

Locher, James R. "Has it worked? The Goldwater-Nichols Reorganization Act." Naval War College Review, 2001: 95-115.

-. Victory on the Potomac: The Goldwater-Nichols Act Unifies the Pentagon. Need City: Texas A\&M University Press, 2004.

McNicol, David L., and Linda Wu. Evidence on the Effect of DoD Acquisition Policy and Process on Cost Growth of Major Defense Acquisition Programs. Root Cause Analysis, Alexandria: Institute for Defense Anaylyses, 2014.

Nemfakos, Charles, Irv Blickstein, Aine Seitz McCarthy, and Jerry M. Sollinger. The Perfect Storm. Research, Santa Monica: RAND Corporation, 2010.

Office, General Accounting. Acquisition Reform: Defense Management Report Savings Initiatives. Defense Management Report, Washington D.C.: National Security and International Affairs Division, 1990. 
Packard, David. "A Formula for Action: A Report to the President on Defense Acquisition." Presidential Commission, Washington D.C., 1986.

Packard, David. "A Quest for Excellence: Final Report to the President." Presidential Commission, Washington D.C., 1986.

-. Management of America's National Defense. Washington D.C.: American Enterprise Institute Press, 1987.

—. The HP Way: How Bill Hewlett and I Built Our Company. New York: HarperCollins Publishers, Inc., 2006.

Peters, Tom. "David Packard's Folly." tompeters! 1986. tompeters.com/columns/david-packardsfolly/ (accessed November 9, 2014).

Petrucci, David. Improved Affordability in DoD Acquisition through Strategic Management of Systemic Cost Risk. Masters Thesis, Cambridge: Massachusetts Institute of Technology, 2005.

Schwartz, Moshe. Reform of the Defense Acquisition System. Congressional testimony, Washington D.C.: Congressional Research Service, 2014.

Unknown. Astro Databank. August 31, 2012. http://www.astro.com/astrodatabank/Packard\%2C_David (accessed February 18, 2015).

—. "Dave Packard Biography." Hewlett Packard. January 2001. http://hp.com/retiree/history/founders/packard/dave.pdf (accessed November 18, 2014).

—. Edison Tech Center. n.d. http://www.edisontechcenter.org/DavidPackard.html (accessed February 16, 2015).

—. Entrepreneur. October 10, 2008. http://www.entrepreneur.com/article/197644 (accessed November 9, 2014).

—. General Electric. n.d. http://www.ge.com/about-us/history (accessed February 16, 2015).

—. Hewlett Packard. 2015. http://www8.hp.com/us/en/hp-information/about-hp/history/hptimeline/timeline.html (accessed February 18, 2015).

—. "Hewlett Packard Corporate Archives." Hewlett Packard web site. January 2004. www.hp.com/retiree/history/founders/packard/dave.pdf (accessed November 19, 2014).

—. The David and Lucile Packard Foundation. n.d. http://www.packard.org/ (accessed February 18, 2015). 
AU/ACSC/SMITH, B/AY15

—. The Pueblo Chieftan. October 16, 2014. http://www.chieftain.com/opinion/2980311119/packard-pueblo-david-hewlett (accessed February 18, 2015).

—. "William Hewlett \&amp; David Packard: Maverick Managers." Entrepreneur. October 10, 2008. http://www.entrepreneur.com/article/197644 (accessed November 18, 2014).

Vigil, Karen. The Pueblo Chieftan. February 1, 2002. http://www.chiefads.com/metro/packardfoundation-cuts-pueblo-funds/article_2fc04cd5-6eb8-5691-b0a8-6dd466d85f57.html (accessed February 18, 2015). 